\title{
9
}

\section{Afghanistan's Cosmopolitan Trading Networks: A View from Yiwu, China}

\author{
Magnus Marsden and Diana Ibañez-Tirado
}

aji Nazar had been living in the city of Yiwu in China's Zhejiang Province for about two years when we first met him in March 2016. ${ }^{1}$ Haji Nazar ran a trading office that arranged the procurement and shipment of merchandise from Yiwu's Futian market and the factories with which it is linked to the port of Rotterdam in the Netherlands. Haji Nazar is a Farsi-speaking Sunni Muslim originally from a rural region of northeastern Afghanistan, but resident for many years in the northern Afghan city of Kunduz. His life has been characterised by mobility. In the mid-1970s he left Afghanistan to study in Saudi Arabia, where he also worked for a time as the cashier of a restaurateur from northern Afghanistan who ran a business in Jeddah, Saudi Arabia's principal port city. At the end of the decade, Haji Nazar was awarded a scholarship to study in the United States, but he was told by officials in the Embassy of Afghanistan in Saudi Arabia that due to a change of regime in his country he would now have to return home to get a new passport to travel to the United States. Haji Nazar returned to Kabul but was immediately arrested by the country's much-feared intelligence agency (KhAd). Having spent some time in jail, Haji Nazar was released and thereafter played an active role in the resistance movement fighting against the proSoviet government of Afghanistan; more specifically, he became a member of 
the Islamist Hizb-i Islami party, led by Gulbuddin Hekmatyar. After some years of fighting with Hizb-i Islami mujāhidin, Haji Nazar began to have doubts about the sincerity of the leader of the regional wing of the party (for whom he also deputised) having seen the commander enter into truces with Soviet officers. Eventually, Haji Nazar decided to leave the resistance and return to Saudi Arabia, a country in which he decided he would be safer than if he moved to Iran or Pakistan. Haji Nazar resettled in the city of Jeddah, where he looked up his prior employer, only to discover that the restaurateur had left the city for Istanbul having had much of his savings 'eaten' by his local sponsor (kafil). Haji Nazar secured work elsewhere in Jeddah, only returning permanently to Afghanistan after the defeat of the Taliban by US forces in 2001, at which point he secured employment as a clerk in one of the many NGOs active in development work in the country. By 2014, however, the scope for employment in such organisations was dwindling in the wake of the withdrawal of foreign forces and a subsequent decline in international development funds being ploughed into 'reconstructing' the country. In the wake of the difficulties in securing employment and therefore also raising his young family, Haji Nazar was approached by one of his relatives - based in the Netherlands having moved there as a refugee - to ask if he would be interested in running an office in China that would be responsible for arranging the export of the goods in which his wholesale business dealt in Europe: souvenirs such as key rings and pens, as well as hashish leaf grinders that are principally sold in Amsterdam to tourists.

Having experience in both travel and working for trading companies, as well as needing money to support his family and his children through higher education, Haji Nazar agreed, and established himself in Yiwu, where we met him in 2016. Haji Nazar's gentle mannerisms and deep knowledge of Afghan trade and mobility ensured that we soon struck up a friendship; his formal education in the Islamic sciences also convinced us that he would be an excellent source of information on the role played by Islam in shaping the commercial activities of Afghan traders (tojiron) in Yiwu and China more generally. We thus asked him how the traders from Afghanistan managed to live according to shari $a$ conventions in Yiwu, especially in such areas of everyday life that saw repeated interactions between Afghan men and Chinese women working alongside one another in trading offices. Haji Nazar 
politely replied that according to shari $a$ a there was an argument to be made for treating such interactions as permissible because traders were 'compelled' to hire Chinese women to work for them as a result of their need for staff with expert language skills. Yet, he went on, we might well also have noticed that a clear majority of the traders of Afghan background in Yiwu were not especially 'bothered in issues relating to sharì'a' (där qissa-i sharì a nistand); he thought such calculations rarely formed part of their thinking.

Haji Nazar's mobile lifestyle distils some of the key concerns with which this book opened: the distinction between the deep forms of Islamic cosmopolitanism traditionally held to be available to travellers to Islamic centres (in the Haji's case, Jeddah) with forms of travel to 'wild spaces' where the Muslim faith is deemed to be at risk from un-Islamic influences. Likewise, Haji Nazar's trajectory also brings attention to the coercive nature of the forms of cosmopolitan-inducing mobility in which he has been involved: his decision to leave Afghanistan has on each occasion arisen in a context of instability, international intervention and violent conflict. And yet the Haji's experiences of life in the centres and peripheries of Islamic Asia cannot be simply defined either in terms of discourses that would treat him either as an Islamist militant or a hapless refugee. There is, rather, the conscious display of irony in the way in which the Haji narrates his life to us: a former mujahidin fighter shows his ability to practically adapt to life in China and also to ship containers of hashish leaf grinders to the shores of Europe. Haji Nazar's mobile life provides a glimpse into a wider world of Afghan mobility, circulation, adaption and exchange.

\section{Yiwu: International Trading City in China}

The ethnographic focus of this chapter is on transnational networks of Afghan commodity traders that criss-cross much of Asia and also the world beyond. An increasingly important node for these networks is the Chinese city of Yiwu. ${ }^{2}$ For Afghan trading networks, the city has become a 'commercial and affective centre' ${ }^{\text {'3 }}$ that is connected to multiple nodes salient for these people's trading activities elsewhere, especially Moscow and St Petersburg in Russia, Odessa and Kharkov in Ukraine, and London, Hamburg and Rotterdam in Western Europe. ${ }^{4}$ Afghan traders are also active in a plethora of settings across Muslim Asia, especially in Saudi Arabia, Turkey, Pakistan and Iran. ${ }^{5}$ 
Located $280 \mathrm{~km}$ from Shanghai, Yiwu is an international hub for the provision of commodities for everyday use and has come to play a central role over the past decade in the worldwide trade in Chinese-made 'small commodities. ${ }^{6}$ The International Trade City, popularly known in Yiwu as Futian, attracts over 210,000 buyers every $\mathrm{day}^{7}$; in addition to the buyers in Yiwu's Huangyuen Market (specialising in clothes), there are other smaller commercial centres dedicated to the sale of auto parts and furniture. Yiwu is also known for its industrial area with factories mainly producing jewellery, hair accessories, socks and haberdashery products. Purposely designed to be an inland Chinese port, 650,000 cargo containers are exported from Yiwu to 219 different countries each year. ${ }^{8}$

With approximately 2 million inhabitants, the city is also a base for merchants from around the world. There are over 14,000 foreign traders who own and/or work in trading and cargo companies involved in purchase and export. In addition, every year Yiwu receives around 400,000 foreign visitors for trading purposes. ${ }^{9}$ Travelling to and being physically present in Yiwu is central to the practices of global commodity traders, who must contend with the risks of being sold faulty goods or seeing the arrival of these in their home ports delayed by the production process, customs officials and port closures. ${ }^{10}$ Traders from all over the world, including overseas Chinese, arrive from Latin America, Asia, the Middle East and Africa to Yiwu in order to provision goods and export these to the markets in which they work.

While Yiwu does attract many business people who do not belong to organised trading groups or networks, ${ }^{11}$ many trading networks of world historic significance are present in Yiwu, including traders of Levantine background from Mexico and Brazil ${ }^{12}$; Yemeni Hadrami traders who hold Thai citizenship $^{13}$; Armenian merchants hailing from Armenia and Iran ${ }^{14}$; Afghans who are citizens of the Ukraine, Russia, the United Kingdom, Holland and Sweden, and who ship goods to all of these countries ${ }^{15}$; and Indians who are active in the trade between Yiwu and many countries in Africa and Latin America. ${ }^{16}$ Not all, but many, of the traders who operate from Yiwu work within and identify with extensively scattered trading communities that bear comparison with trading networks, ${ }^{17}$ such as the Sindhi networks studied by Claude Markovits and Mark-Anthony Falzon, ${ }^{18}$ and the West African Muslim Murids whose activities in Africa, Europe and the United States have been 
documented by scholars including Beth Buggenhagen and Mamadou Diouf. ${ }^{19}$ Of all these foreign traders, those arriving from West Asia constitute the majority in Yiwu. ${ }^{20}$ Especially visible in the city are traders from Syria, Egypt, Algeria, Palestine, Iraq (both Arabs and Kurds) and Iran (Persian, Azeri and Kurds). Yiwu thus is an important meeting point for long-distance trading networks, and a city that has come to be thought of by the city's inhabitants and its international visitors as especially attractive to Muslim traders. ${ }^{21}$

\section{Islamic Cosmopolitanism: Analytical Starting Points?}

It is impossible to understand the nature of the Muslim networks and connected forms of cosmopolitanism described and analysed in this chapter without considering these in relationship to modern forms of economic globalisation. Anthropologists are now making considerable headway in documenting and understanding such forms of global connectedness. On the one hand, there is a growing body of literature that analyses such forms of trade as being a distinctively 'bottom-up' form of globalisation. ${ }^{22}$ On the other hand, those involved in such processes are widely depicted as adapting to the global economy or having become traders as part of a survival strategy developed to deal with hard times that reflect the legacy of structural readjustment and neo-liberal forms of capitalism. ${ }^{23}$ These studies have brought a great deal to the understanding of the types of networks and connections upon which the global trade in low-grade goods depends.

Scholars have also increasingly recognised that globalisation from below and globalisation from above are interpenetrated. For example, Keith Hart suggests this distinction, and that between formal and informal forms of economic phenomena, can lead to the assumption that 'informal' economic practices, concepts and institutions are of significance only in the world's 'peripheral spaces'. In turn, this obfuscates the ways in which 'the global economy' at large has undergone 'informalisation' over the past two decades. ${ }^{24}$ It is also commonly acknowledged that the success of trading cities such as Yiwu, and consequentially its connected outposts around the world, depends on the policies of nation-states and local authorities, their willingness to turn a blind eye to practices such as the import and export of counterfeit goods, and, indeed, the participation of their personnel in such processes. ${ }^{25}$

In this chapter we reflect upon a network made up predominantly, 
though not exclusively, of people of Muslim background that has come to fill important niches in the forms of economic activity identified analytically as 'globalisation from below'. In light of this volume's overall concerns, we are interested in reflecting on the extent to which the Afghan traders who are the focus of the chapter are helpfully conceptualised as being 'Muslim cosmopolitans' or, indeed, the creator-participants of expansive forms of 'Islamic cosmopolitanism'. Before proceeding to the ethnographic sections of the chapter, which explore the nature of the networks formed by traders from Afghanistan, as well as the modes in which such traders inhabit the city of Yiwu, we wish to make two general points about the relevance of the notion of 'Islamic cosmopolitanism' to this case study.

First, early anthropological work on globalisation argued that a range of mobile actors - including preachers, working-class labour migrants and even 'refugees' - were fashioning hybrid and cosmopolitan identities. By crossing the boundaries of nation, ethnicity, culture and religion, migrants and the flows of finance, technology and culture they engendered, invigorated and forged open-ended, or 'cosmopolitan', forms of self and subjectivity. More recently, however, scholars have tempered their emphasis on the opening if not liberating effects of globalisation. Mobility does not inevitably result in the fashioning of open-ended forms of self and society or the apparently effortless achievement of unqualified human openness: it often leads to the production, rather, of heightened forms of attachment to locality. ${ }^{26}$ 'Mobility, flows and the transgression of boundaries' according to Ulrike Freitag and Achim Oppen (p. 4), ${ }^{27}$ are leading to the production of ideas about globality, yet people in the midst of experiencing such processes often attempt to 'cope with transgression' by localising 'some kind of order', rather than celebrating their having come to inhabit a 'global space'. The term 'global' itself, moreover, is often deployed in a 'complacent' manner that suggests an ever-expanding scale of progressive possibility, connected, in recent times, to forms of humanitarianism that justify political intervention in 'failed states' on the grounds that their inhabitants have not lived up to the standards of 'global civilisation': Paul Gilroy captures the paradoxes implicit in a such processes by referring to the forms of humanitarianism practised in Iraq and Afghanistan over the past decade and more as reflecting an ideology of 'armoured cosmopolitanism', a concept that bears some similarity to the notion of coercive cosmopolitanism introduced by the 
editors in the opening pages of this book. ${ }^{28}$ In the context of both these analytical debates, as well as Afghanistan's history as a testing ground for modern ideologies over the past century and more,$^{29}$ the notion of Islamic cosmopolitanism needs to be applied to the ethnographic material on which this chapter is based with caution. The mobile and highly flexible actors (including Haji Nazar) explored below have both witnessed the 'armoured cosmopolitanism' visited upon their home country as well as come to lead mobile lives as a result of the coercive policies of the foreign powers active there.

Secondly, we have come to see how important it is not to take the Islamic aspect of the worlds created and inhabited by Afghan traders for granted. Afghan traders' self-understandings, social relationships and ties with host communities and state officials, as well as the tactics that such people deploy to cross international boundaries, reveal them as being highly flexible social actors. This flexibility is evident at varying intersections of everyday life. One of the themes that we focus on in this chapter, for example, is the traders' understandings of what being Muslim and 'Afghan' means and how this affects their modes of forging relations with one another and the people in whose midst they live. People who are part of trading networks often showcase their capacity to be versatile and adaptable in their religious lives and the ways in which doing so allows them to 'span religious and cultural divides as well as continents and oceans' (p. 79). ${ }^{30}$ We suggest in what follows that Afghan traders are people whose lives are not one-dimensionally geared towards making a homogeneous 'Islamic space' or a globally oriented form of 'Muslim network'. It is more helpful to think of our informants, rather, as being men who value their capacity to diplomatically mediate between and profit from arbitrages between different types of spaces. ${ }^{31}$ They are individuals who embody connections to one another that are as much about trade and pragmatism as about being Muslim. ${ }^{32}$ If in the Kantian tradition the notion of cosmopolitanism arose as a requirement to temper the nationalist extremes of the modern nation-state, many traders from Afghanistan emphasise their capacity to achieve prestige and repute by moving across transregional spaces that transcend, yet not in a manner that contests the boundaries of such nation-states. The ways in which they do so challenges the notion that being Muslim in a global and cosmopolitan way inevitably results in hostility towards the idea of the nation-state. ${ }^{33}$ 


\section{Beyond Diasporas: Poly-stranded and Multimodal Trading Networks}

The traders from Afghanistan with whom we have been working do not form a homogeneous 'diaspora' in the conventional sense of collectively defining themselves as belonging to a group from a shared geographical locale that is able to trace its origins back to a single moment of dispersal. The traders are better thought of, rather, as forming poly-stranded and multimodal trading networks. ${ }^{34}$ The traders' networks are poly-stranded in that while they are made up by individuals willing to describe themselves as being 'from Afghanistan', they are simultaneously organised in relationship to specific regional identities; the specific nature of the networks play a critical role in shaping the particular commodities in which individual traders deal, as well as the geographical contexts in which they operate. The networks are multimodal in that the collective trading activities of merchants from Afghanistan do not rely on a single, central node in which information is shared and capital distributed but, rather, on multiple and interlinked nodes, none of which is significantly more influential than the others.

The different networks that people from Afghanistan form collaborate with one another, but more often specialise in either different merchandise or in the distribution of commodities to distinct geographical regions. Traders in Yiwu who freight goods from China to Afghanistan are especially numerous. Such traders belong to various ethnic groups (though many are Pashtospeaking Pashtuns from Afghanistan's eastern provinces and Farsi-speaking Tajiks from provinces to the north of Kabul). Such traders are mostly Sunni, but there are also several and well-established Shi ' 1 traders involved in the trade in commodities of daily use between China and Afghanistan. In Yiwu, these traders have forged high degrees of commercial organisation. They have established committees that seek to define and delimit the price of shipping containers to Afghanistan. As we shall see below, the traders organise weekly meetings in Yiwu at which information about business and the activities of traders is shared. Their ties and obligations to one another are repeatedly established and sustained in relationship to shared Islamic rituals, especially those performed during Ramadan (the organisation of tarawih prayers and iftar feasts), as well as charitable feasts (khayrat) that mark the death of relatives back home in Afghanistan (faitiha). These merchants also forge close 
ties with the state of Afghanistan, most especially the Kabul-based Chamber of Commerce.

A second network comprises traders working across the former Soviet Union, though especially in Russia and Ukraine. These traders are ethnically mixed (being both Persian and Pashto speakers, as well as including a much smaller number of Uzbek speakers). Nevertheless, despite differences in language and ethnicity, such traders do tend to share an ideological commitment to 'being Afghan' (partly derived out of past membership of the People's Democratic Party of Afghanistan) as well as shared educational experiences - most studied in higher education institutes in the Soviet Union during the late 1980s. Indeed, the long-term workings of coercive cosmopolitanism are especially visible in the membership of this trading network. Amongst traders working in the former Soviet Republics are individuals who initially travelled to the region as part of Soviet programmes that placed Afghan orphans in Soviet boarding schools (internat) in the 1980s with the aim of creating a cadre of loyal pro-Soviet government servants. ${ }^{35}$ At the same time, however, that commitment to Afghanistan reflects the country's modern history and its relationship to the Soviet Union, the specific niche activities of traders tends to be organised in relationship to their regional backgrounds. For example, in the Ukrainian port city of Odessa, home to the Seventh-Kilometre market, the import of children's scooters and roller blades from Yiwu is carried out largely by traders from Afghanistan's northeastern Badakhshan Province; by contrast, the import of umbrellas from China as well as their sale in the Ukraine is dominated by traders from Panjshir; the business in hardware items is largely handled by traders from the eastern provinces of Khost and Paktika, both Hindu and Muslim in terms of religious affiliation (see below). Importantly, though, not all of the sub-networks are formed in relationship to regional identity - shared professional experience can also be important in defining their nature. For example, during fieldwork in Yiwu we encountered a trading company that was involved in the export of goods to Russia and Ukraine, the partners of which included Pashto and Farsi speakers from different regions of the country who had all served as pilots during the 1980s in Afghanistan's air force.

Traders able to import goods from Yiwu to the former Soviet Union tend to be well established in Russia and Ukraine and lead stable lives. Many 
traders live with their families in the cities in which they work (St Petersburg, Moscow, Odessa and Khakov being key nodes); they hold the passports of Russia or Ukraine and also own property there in the form of shops, warehouses and homes. We have explored elsewhere the role played by marriages and informal relationships between Afghan traders and local women to the activities of traders in the former Soviet Union. ${ }^{36}$ Such marriages root mobile merchants in particular contexts and therefore also ensure the durability of such settlements as nodes for commercial activities over time. Local wives also bring critical skills to the trading activities of Afghan traders in this region of the world: they offer insights into the changing fashions of the populations they serve. For this reason, many traders travel with their wives to China at least once a year to ensure they get valuable input in terms of the orders they place with their Chinese suppliers. Importantly, while some women married to Afghans in Russia and Ukraine do convert to Islam, this is by no means the norm or even something that is expected by individual traders or the wider networks they form. Several traders have remarked to us that if they had wished to marry a Muslim there was no shortage of women in Afghanistan to choose from: they were interested, rather, in women they could trust and build a relationship with based on sincerity (ikblas).

In recent years, these networks have increasingly demonstrated their dynamism and responsiveness to changing geopolitical circumstances. A significant market for goods sent from Yiwu to Odessa, for example, was Crimea. The annexation of Crimea by Russia in 2014 made this trade route increasingly complex for Ukraine-based Afghans. Nevertheless, within months of Crimea's annexation several Odessa-based Afghan traders had moved to Sevastopol in Crimea, either bringing their goods from Ukraine using illicit routes or exporting directly from China to Crimea via Russia. In recent years, traders based in the former Soviet Union have increasingly penetrated the markets of Western Europe: traders have migrated from the former Soviet Union to countries in the European Union and gradually established trading activities in the cities to which they have moved; others have supplied goods sourced in China to relatives who have migrated from Afghanistan to Europe (often as refugees). Indeed, traders based in the former Soviet Union are developing increasingly complex business models. A trader yet to receive identity documents in the country in which he is based, for 
example, might appoint his UK-based brother to an office in Yiwu thereby ensuring a steady flow of goods from China to Russia or Ukraine. Similarly, a trader based in Ukraine who has relatives in Afghanistan in need of work might arrange for someone to move to Yiwu in order to open a trading office that supplies him with the goods he requires. It goes without saying that such responsiveness to changing geopolitical contexts requires globally-oriented forms of knowledge and skill: the ability to interact with Russian officials in Crimea, for example, or the willingness to learn Chinese.

A third network that we have identified in Yiwu is made up of traders who work between China and the Gulf states, most especially Saudi Arabia but also the UAE and Oman. Most traders working in Saudi Arabia identify themselves as being Uzbek- and Turkmen-speaking people who are the descendants of migrants who came to Afghanistan from Central Asia after the Bolshevik Revolution began to affect the organisation of their societies in the 1920s. These traders - who mostly procure clothing and machine-made carpets in Yiwu - are helpfully conceptualised as forming a 'mobile community ${ }^{37}$ : having left Central Asia in the 1920s they lived first in Afghanistan and then Pakistan; today they regularly divide their lives between Saudi Arabia (where they own wholesale businesses) and Turkey (a country in which they own homes, carpet and clothing factories, and frequently educate their children). ${ }^{38}$ Traders operating in the UAE and Oman also include Central Asian émigrés active in the sale of machine-made carpets, though in numerical terms merchants who identify themselves as belonging to Pashtun tribes from the eastern region of Paktika are most visible. These Pashtun traders are active in the sale of cloth, including silks and chiffons, from Yiwu and the nearby town of Keqiao to the Naif market in Dubai: from there, the cloth is distributed to a range of markets across the Gulf. ${ }^{39}$ These traders, however, are considerably more involved in the economy of Khost than the more mobile Central Asian émigrés. Gulf-based merchants have played an active role in the property market of eastern Afghanistan, as well as the opening of various higher education institutes.

There is a third type of more complex and multimodal network that criss-cross different geographies. Traders from regions of Afghanistan that are known for having reserves of precious and semi-precious stones (such as Panjshir, Badakhshan and Ghazni) often lead highly itinerant lives taking 
stones mined in Afghanistan for polishing in Jaipur and for sale in cities across China. Such traders also procure stones in Bangkok and sometimes in Congo and Zambia; their travels are often facilitated by them holding passports of the countries that have become their home and that are also key nodes for their business activities (including Germany, South Korea, Japan, the United States and Hong Kong). Indeed, Marsden has spoken with several traders from Afghanistan who hold US passports and are involved in the gemstone trade between various Latin American countries (especially Peru and Mexico) and Hong Kong. Although these types of gemstones are traded by merchants of diverse nationalities from Yiwu's Futian Market District 5 (a section of the market that is devoted to the sale of goods imported to China), the city itself is not an influential node in the global gemstone trade. Nevertheless, these Afghan traders are present in Yiwu as a result of the city's relatively streamlined administrative procedures, which makes Yiwu a good place to open a trading office and apply for the relevant category of Chinese visa.

Finally, while the networks introduced above are made up either of people who would identify themselves as being Muslim in one respect or another (though of course holding very different attitudes towards Islam and what its practice entails), Afghanistan's international trading networks also include substantial communities of non-Muslims. In particular, Afghanistan's Hindu and Sikh communities are especially active in long-distance trade. Historians have demonstrated the historic importance of such groups to Afghanistan's commercial relations with both South Asia and Eurasia. ${ }^{40}$ Since the civil war of the 1990s, however, most of Afghanistan's Hindu and Sikh families have left the country, migrating primarily to India, Russia or Europe (especially London and Hamburg). In these contexts, Afghan Hindu and Sikh traders import commodities from China (especially Yiwu) and sell these on cash (pull-e narkh) or on a credit (qarz) basis to Muslim traders from Afghanistan working in the same settings. We are often told during the course of fieldwork how the majority of Afghan businesses run by Muslims in Russia rely on traders who identify themselves as Hindu and import commodities to Moscow from China. Indeed, Hindu and Sikh traders from Afghanistan are a visible feature of life in Yiwu: they regularly hold evening parties for their guests coming from one or other of the contexts in which the community 
is located. Afghan Muslim traders are open about the important role that Hindu and Sikhs have played in their business activities, often saying that it would have been impossible to commence trading abroad if the country's 'Hindus' had not been willing to provide them with goods on credit. ${ }^{41}$

Geographically, therefore, the traders are active globally, though, as noted above, particular networks specialise in the trade in commodities between relatively well-defined regions. In terms of ethnicity and regional identity, some networks are more homogeneous and cohesive (e.g., Central Asian émigrés) than others (Yiwu-Afghanistan traders). Yet given that they operate in nodes like Yiwu where multiple networks coalesce, all the networks ultimately establish relationships with people from Afghanistan who identify with different groups than their own. Indeed, whether traders based in Yiwu from Afghanistan are working in the markets of Russia, Afghanistan or Saudi Arabia, they are often strongly encouraged by the community to attend a weekly Thursday evening social gathering (majlis ijtimoye) that is held in an Afghan-owned shisha parlour. During the gathering, traders share information about the conditions in the settings in which they are working, including legal and policy changes in Yiwu that affect their practices and everyday lives in the city. Far from being either the one-dimensional victims of the instability of their home country or the type of persons that are easily lured by the cosmopolitan visions of global Islamic community or a re-imagined caliphate, these traders and their networks are increasingly successful, well established and able to profit from the many different settings and countries over which they operate.

\section{A Walking Tour through Yiwu}

Yiwu has been widely represented in the media and more scholarly accounts as being the supermarket of the Arab world: not only is the mix of traders that travel to the city far more diverse than this image suggests, but so too do traders from many more parts of the world than the Middle East and Africa visit the city as commodity traders. ${ }^{42}$ Over a period of seven months in 2016, we conducted several fieldwork exercises in order to map the trading communities that are a relatively stable and established feature of Yiwu's landscape. Surveys concerning the backgrounds of the foreign traders were conducted on a daily basis in the Five Districts of Futian Market, weekly 
visits were made to the Wu Ai stock market and Huanyuen Garment Market, and we also undertook a detailed spatial analysis of Chouzhou $\mathrm{Lu}$ - the main artery connecting the city to Futian Market. We also spent time exploring the Bingwan Night Market (there are several retail shops in the market that are frequented by foreign visitors keen to buy presents to take home or seek inspiration for new products to purchase at a wholesale level) and interviewing the owners of numerous international restaurants in the city. Finally, we also conducted participant observation with owners of foreign companies and their staff, as well as with foreign traders who had enrolled into schools that offered Chinese-language lessons tailored to the needs of business people. We were invited on occasions to accompany foreign traders to place orders in Futian and nearby factories, to receive merchandise from suppliers in warehouses, and to fill containers in Yiwu's inland port.

Let us take the reader on a brief walking tour of Yiwu in order to give a sense of the many communities present in and their distribution through space in the city. We will treat the city's main artery (Chouzhou Lu) as the basis for our tour. The neighbourhoods of Futian Second District and Changchun are located in the part of Chouzhou Lu closest to the Futian Market. These areas of five-storey apartment buildings, which include the Futian Tower, are used for both living and commercial purposes. This zone is popular amongst Russian, Iranian, Azeri, Ukrainian, Uzbek, Kazakh, Turkmen, Tajik and Afghan trading companies. While diverse, in this part of the city the main international languages of trade and sociality are Russian, multiple Turkic languages (especially Uyghur, Uzbek, Azeri, Turkmen and Kazakh), and Persian (Farsi, Dari and Tajik). ${ }^{43}$ The area is also the site of many wholesale shops selling jewellery and beads, as well as Uyghur, Central Asian and Afghan restaurants catering for foreign visitors and, on occasion, their Chinese guests. This area is not homogeneously made up of traders from post-Soviet Central Asia and neighbouring regions; Changchun is also an attractive space for Latin American traders and companies, especially those from Colombia and Bolivia.

Further down Chouzhou Lu in the direction of the city centre the walker will come to a crossroads at which two landmarks famous amongst Yiwu's foreign traders are located: the Jimao and Jimei Towers. Numerous Afghan companies run offices in these buildings, as well as two rooms popularly 
called 'mosques' that are mostly used by worshippers from Afghanistan to conduct their daily prayers. On a street perpendicular to Jimao Tower lies a zone that is noticeable for a preponderance of Indian restaurants, hotels and trading companies. Between these Indian-characterised streets and Zongze Road, there are several buildings dedicated mainly to the wholesale of Christmas decorations, LED-lights, beads, supermarket trolleys, shelves and mannequins, along with the odd Nepali eatery. As the walker proceeds closer to the city centre, she or he will begin to encounter clusters of Afghan and Iranian companies - the latter mainly being run by Kurds who ship goods from Yiwu to the Iraqi sectors of Kurdistan and from there, by road, to the many commercial border cities in the Iranian provinces of Kurdistan and Azerbaijan. Unsurprisingly, the restaurants in this area of Yiwu included the now closed 'Tehran' and the unambiguously named 'Kurdistan'.

Another important intersection in Yiwu is the crossroads of Chouzhou Lu and Zongze Road. This intersection is home to a restaurant that has become a well-known geographical reference point in Yiwu: 'Ariana', an Afghanowned eatery that, with over ten years of service, has come to be thought of by traders as being a high-end establishment, and is said to have captured a significant portion of the city's culinary market. Afghans often remark that the establishment's owner (a Farsi-speaker from northeastern Afghanistan) was clever to choose this particular location: a 'crossroads' (chahrahi) on the route taken by traders between the market and the city, it captures the attention of everyone in the city. Even Chinese taxi drivers unmistakably know the location of 'Ariana' - meaning that the corner where the restaurant stands is now also a popular meeting point. On the opposite side of the road, an Afghan competitor opened another restaurant to the public a couple of years back, although its cheap buffet finds Ariana and its hard-won clientele a tough act to follow. There are further Afghan establishments in this part of town: a café ('Qasr-e-Shirin', or Palace of Sweets), and 'Kabul Darbar'- an eatery popular with some Afghans but mostly with Arabs and Pakistanis.

About 10 minutes further down the street the walker will encounter the central office of the Bank of China (noticeable for the throngs of Hui foreign currency dealers standing outside): this building marks the first signs of the influence of 'the Middle East' on Yiwu's urban space. An Egyptian restaurant and a joint Turkish-Syrian venture are popular for food and 
shisha amongst traders from the Middle East, although Afghanistan's Central Asian émigrés also organise their iftar feasts here, saying they have come to appreciate Turkish food during their many visits to Istanbul. There are also retail shops owned by Syrian traders that sell clothing (especially veils, 'abayas and dresses aimed at Muslim women), as well as retail shops (also owned by well-established Arab traders from the Middle East) selling electronics and lights. ${ }^{44}$ On the corner of Chouzhou Lu and Bingwan Road, the famous 'Sultan' restaurant can be found, which offers Turkish cuisine and is frequented by traders of all nationalities. From 'Sultan' further down the street there are a string of Middle Eastern establishments, including a Syrian-owned supermarket, a Syrian butcher, as well as another Turkish restaurant. This Turkish establishment is often frequented by Russian-speaking traders as the restaurant staff speak Russian because the Turkish businessman who owns it is married to a woman from Belorussia. Nearby, there is the bar-restaurant 'Moscow' offering Russian and European cuisine as well as live music performed on occasion by a Mongolian student married to a Russian woman. At the frontiers of this Turkish-Russian area can be found an Iranian restaurant (Shirin): Shirin's sober and typically Iranian interior (including a small fountain and traditional raised wooden benches, or takht, on which diners may recline and relax while drinking tea and taking a qailoon) is in contrast to the nightclub below 'Empire', which is renowned for its attractive Russian female entertainers or 'party girls'. As the walker continues her or his stroll down Chouzhou Lu she or he will come across several Arab establishments and also an increasingly lively street scene: MC Café, for example, is usually full of traders from Algeria, Mauritania and Morocco, seeking good coffee and a chair on the kerb. Nearby is Bubus Café, owned by a trader from Bosnia, and next to Bubus, are two restaurants owned by Coptic Egyptians - a good escape for traders (and fieldworkers) attempting to find something to eat in the day during Ramadan.

In this zone, McDonald's is typically full of Chinese and foreign traders seeking a fast and cheap meal and a good view of the road towards the park that lies opposite and the popular Bingwan Night Market. Between the night market and the area officially called Bingwan, but popularly known as Maedha (after a famous Egyptian-owned restaurant), there are dozens of establishments owned by Arabs, including the Syrian restaurants 'Aleppo' and 
'Damascus', the Kurdish-Iraqi-owned 'Shakhawan', the Chinese-owned but Iraqi established 'Erbil', and the Yemeni 'Sabah', which is especially popular amongst traders from East Africa (Ethiopia, Kenya, Somalia and Tanzania). An Afghan restaurant was also established in this area, though it was unsuccessful because, as one trader told us, everybody already has their 'own line' in this part of the city and an Afghan eatery did not fit in. In this otherwise distinctly Middle Eastern space, the Bingwan night market is a context in which Chinese shopkeepers and foreign visitors meet on a daily basis for shopping, strolling and relaxing in the evenings. The area around the night market is thus home to numerous Uyghur-run restaurants, mini-markets and stalls selling barbecued meat, as well as vendors of Chinese street food, the smell of which is a constant source of complaint by our Afghan informants. A short ride by taxi from this night market is to be found in the $\mathrm{Wu}$ Ai area, home to numerous trading companies owned by Arabs, as well as restaurants from the Middle East, including the Yemeni 'Shibam'. Wu Ai is one of several neighbourhoods in which foreign traders with families prefer to live.

\section{Living the City}

If the above description covers the areas running along Chouzhou $\mathrm{Lu}$ from Futian market to the night market, elsewhere in the city mixed and multinational forms of sociality are more pronounced. For the children of traders who run established companies in the city, there are several foreign schools that have been opened and are managed by foreigners, including the Chinese-Egyptian Modern School and the Rainbow Kids preschool near Yiwu's central mosque. The latter preschool is staffed by female teachers from Muslim backgrounds, including both foreigners, Chinese Han who have converted to Islam, as well as Uyghurs and Hui. The owner of the school has also popularised electronic books that help Muslims seeking to memorise the Qur'ān. Yiwu is indeed home to growing communities of people of Muslim background from elsewhere in China, especially Hui Chinese-speaking Muslims who migrate to the city from the provinces of Yunnan, Nagxi and Gansu, and Uyghurs from various locales across Xinjiang. ${ }^{45}$ Yiwu's Muslims - foreigners and Chinese citizens - tend to gather on Fridays at the city's mosque (a former silk factory) that was completed in 2012, thanks to donations made by local and foreign Muslims, including one donation in the form 
of several tonnes of Iranian marble. It is calculated that every week 7,000 people attend the mosque. ${ }^{46}$ Yet, in addition to this busy mosque, Yiwu also hosts several officially registered and non-registered places of worship; many of the Muslim restaurants mentioned above also house prayer rooms for Muslims. There is also a Hindu temple inside the Futian market, several Catholic churches with services in Spanish, English, Korean and Chinese, as well as a Protestant and a Coptic church - the latter being frequented by Egyptian, Syrian and Sudanese Christian merchants, as well as converted Han Chinese.

It is in the field of religious practice that the traders from Afghanistan with whom we are acquainted are most circumspect about their daily behaviour in Yiwu. Few of the traders in the city are especially public or ostentatious about their religiosity, except in terms of their having undertaken the bajj pilgrimage, a ritual that even Afghans in their thirties based in Yiwu have performed on several occasions. Indeed, traders often remarked to us that in China the local police are less concerned about Muslim foreigners if they knew they drink and attend nightclubs than if they are perceived to be particularly pious and God-fearing. During Ramadan, however, tensions between traders from Afghanistan willing to organise religious events and the local authorities who are suspicious of such activities do arise. In June 2016, for example, traders from Afghanistan owning hotels that in previous years had been used as venues for prayer gatherings, Qur'ānic recitations and ifțar feasts were told by the local authorities that such gatherings could be held only in rooms especially designated for such purposes. This change in state attention was believed to have been caused by security concerns arising from the G20 meeting scheduled to be held in Hangzhou around that time.

To what extent are forms of mixing across ethnic, regional, national and regional groupings an aspect of the everyday sociality of foreign traders based in Yiwu? Islamic cosmopolitanism (or the promise of it) requires Muslims and non-Muslims from very different backgrounds to jointly participate in establishing open-ended relationships. At first glance, the spatial organisation of Yiwu reveals above all else the importance of the nation-state and the ethno-linguistically defined region as being the salient markers of the identities of the traders. As we have seen above, particular city districts have been shaped as distinctively 'post-Soviet', 'Indian', 'Arab' or 'Afghan' by the day- 
to-day activities of foreign traders. Importantly, however, if Yiwu appears at first sight to be organised in relationship to ethnicity or nationality, then the spaces delimited above correspond more to trans-regional borderlands than to nation-states per se. Traders from Afghanistan and Iranian Kurdistan own businesses cheek by jowl, for example; at times, Kurdish Iranians find in some Afghan traders the ideal companionship to discuss their common Sunni identity or the politics and tensions between Sunni and Shi' $\bar{i}$ in their respective nation-states. While the Iraqi Kurdish restaurants in the 'Arab quarter' are visited by Iranian Kurds (who are often also cross-border business partners), Russian-speaking Afghans frequently gather in a Tajik restaurant to talk to their Central Asian peers and their Russian-speaking Han Chinese associates hailing from cities along the China-Russia border. Similarly, the Arab area of the city is a complex mixture of traders who are not only Arab but also from settings across East Africa. The preponderance of spaces catering to Muslims from distinct borderlands reflects, more generally, the role that such types of geopolitical spaces and their populations are playing in processes defined as collectively forming 'globalisation from below'.

But whilst ethnicity and regional identity have contributed in significant ways to the distribution of businesses and the organisation of public space in Yiwu, how do Muslims living in the city inhabit the city on a daily basis? Many of the Afghan traders with whom we have spent time, for example, confessed to preferring to spend their evening leisure time in parts of the city that were not clearly marked out by their businesses or clientele as being particularly 'Afghan'. This reflected multiple concerns on the part of traders. Traders of Afghan background visiting Yiwu from the former Soviet Union often remarked to us that their attitudes were distinct from those of their countrymen based in Afghanistan: as a result, they preferred to spend their time in parts of the city that were Russian or 'international' rather than in the cafes and restaurants run by their compatriots. Only by doing so, they admitted, could they enjoy a drink in a street-side cafe owned by an African and soak up Yiwu's distinctive atmosphere. Thus, a group of traders with whom Marsden spent several nights at shisha parlours preferred to visit establishments owned by Arabs and Iranians rather than members of the Afghan community. Other Afghan traders who have been based in Yiwu for years and spoke fluent Chinese told Ibañez-Tirado that they preferred to spend their 
day off at barbecues organised by their Chinese friends at which litres of beer were available, and that would usually end up at raucous KTV's karaoke bars where other Afghan visitors, or indeed, Muslim traders, would rarely venture. Further informants - often those based permanently in Yiwu rather than men visiting the city on short-time procurement sorties from the settings in which they owned businesses - also remarked that they could talk more openly to one another about their business activities in parts of the city where there were less likely to be other Afghans. In terms of the choices that traders from Afghanistan make about leisure and sociality, then, the willingness to experience spaces other than those simply designated as 'Afghan' or 'Muslim' is an important part of their modes of experiencing and inhabiting the city.

Importantly, there are a range of activities undertaken by traders in Yiwu that are premised upon establishing relationships with people from backgrounds different from their own, including those that traverse the boundary between Muslim and non-Muslim. For many of the traders, Saturday night is the evening of the week in which it is normal to relax and spend time with friends, mostly in one of the two nightclubs that are frequented by the city's foreign traders. With a distinctively Latin atmosphere, as salsa music and similar rhythms are usually played in these disco-bars, such venues are preferred sites of relaxation for the numerous women from countries such as Ethiopia, Italy, Russia, Brazil, Bolivia and Mexico who work and live in Yiwu as traders, commodity designers and company managers. On one Saturday, for example, Marsden was invited to join a group of traders from northeast Afghanistan on a trip to one of these nightclubs. The traders (including one who was referred to by his friends as Haji having undertaken the pilgrimage to Mecca) told Marsden that they hoped that he would be able to use his limited Spanish to help them meet women from Colombia who also attended the nightclub. The evening did not progress according to the traders' expectations, however: the men had anticipated being able to find a table around which they could sit and survey the dance floor, yet because it was a busy evening in the club, they were forced to stand awkwardly, and to their minds demandingly, at the edge of the bar. It was collectively decided - after they had ruefully remarked to Marsden that at least he could enjoy a beer, something they were unable to do - that there was no point spending further time in the nightclub. Having bid goodbye to the traders, Marsden spent the 
remainder of the evening with a small group of traders from Kabul and their Chinese girlfriends.

\section{Conclusion}

The focus of this chapter has been the city of Yiwu and the nature of Afghan networks present in the city. By inserting such networks both in the context of the wider global settings and in terms of the traders' experience of space in Yiwu, we have sought to contribute to an emerging body of literature on Muslim cosmopolitanism in two ways. First, we have brought attention to the ways in which the expressions of Muslim cosmopolitanism visible in Yiwu are premised on violent histories of international conflict and interference that have led to massive displacements of the country's people, as well the bleaching out of the country's own religious diversity. ${ }^{47}$ Secondly, it is also important to recognise, as others have ${ }^{48}$ that if the traders with whom we work are cosmopolitan in some aspects of their lives, then in others they reinforce and sustain collective commitment to national, regional, ideological and confessional identities, identities that are also of critical significance to their activities as traders.

Besides, the Afghan traders whose lives are presented in the chapter bring attention to forms of mobility that are very different from those associated with commonplace understandings of Afghanistan. Whereas much scholarship and popular writing on Afghanistan points to the centrality of the flight by refugees and labour migrants to the West to contemporary forms of Afghan mobility, the people with whom we work travel across a wide range of Asian and Eurasian settings, most often in connection with their activities as commodity traders and transporters. The extensive, cyclical and repetitive nature of such journeys and connections reveal the role that these traders have played in forging long-distance trading routes and establishing durable nodes for their activities. Conventional treatments of Afghanistan would no doubt link such forms of movement to one or another form of illegality, be it money laundering or heroin trafficking. We have brought attention rather to the many skills and capacities that these mobile traders bring to their work, be they in terms of the ability and willingness to speak multiple languages, engage with and respond to geopolitical transformations, establish relationships with local authorities, and enter into long-term and 
mutually reinforcing relationships with women of diverse ethno-national and religious backgrounds. In these respects, the everyday lives of these traders suggest the possibility of the promise of open-ended forms of cosmopolitan Muslim identity, forms of cosmopolitanism moreover that are premised on relationships with Muslims and non-Muslims.

\section{Notes}

1. This work was supported by the European Research Council (ERC) under the European Union's Horizon 2020 research and innovation programme 669132 - TRODITIES, 'Yiwu Trust, Global Traders and Commodities in a Chinese International City'. It has also benefited from a grant from the British Academy Small Grant scheme, 'Global Traders in a Chinese International City'.

2. Marsden, Magnus, 'Crossing Eurasia: Trans-Regional Afghan Trading Networks in China and Beyond', Central Asian Survey 35(1) (2016): 1-15.

3. Arsan, Andrew, Interlopers of Empire: the Lebanese Diaspora in Colonial French West Africa (London: Hurst, 2014).

4. Marsden, Magnus, Trading Worlds: Afghan Merchants across Modern Frontiers (London: Hurst, 2016); Marsden, 'Crossing Eurasia'; Marsden, M. and IbañezTirado, D., 'Repertoires of Family Life and the Anchoring of Afghan Trading Networks in Ukraine', History and Anthropology 26(2) (2015): 145-64.

5. Marsden, Magnus, 'Islamic Cosmopolitanism beyond Muslim Asia: the Case of Odessa and Yiwu's Trading Relationship', History \& Anthropology 29(1) (2018): 121-39.

6. Bodomo, Adam, 'The African Trading Community in Guangzhou: An Emerging Bridge for Africa-China Relations', China Quarterly 203 (2010): 693-707; Bodomo, Adam, Africans in China: a Socio-Cultural Study and its Implications for Africa-China Relations (New York: Cambria Press, 2012); Pliez, Olivier, 'Following the New Silk Road between Yiwu and Cairo', in G. Mathews, G. Lins Ribeiro and C. Alba Vega (eds), Globalization from Below: the World's Other Economy (London: Routledge, 2012) pp. 19-35.

7. Jacob, Mark. D., Yiwu, China: a Study of the World's Largest Commodity Market (Paramus, NJ: Homer \& Sekey, 2016).

8. Jacob, Yiwu, China.

9. Marsden, 'Crossing Eurasia'; Ibañez-Tirado, D., 'Hierarchies of Trade in Yiwu and Dushanbe: the Case of an Uzbek Merchant Family from Tajikistan', History \& Anthropology (forthcoming). 
10. See, for example, Haugen, H. O., 'Chinese Exports to Africa: Competition, Complementarity and Cooperation between Micro-Level Actors', Forum for Development Studies 38(2) (2011): 157-76; Li Zhang, 'Ethnic Congregation in a Globalizing City', Cities 25 (2008): 383-95; Yang Yang, 'African Traders in Guangzhou: Routes, Reasons, Profits and Dreams', in G. Mathews, G. Lins Ribeiro and C. Alba Vega (eds), Globalization from Below: the World's Other Economy (London: Routledge, 2012), pp. 154-70.

11. Skrviskaja, Vera, “"The Russian Merchant” Innovation in Contemporary China: Culture(s) of Mistrust, Moral Economy and Economic Success', History \& Anthropology (forthcoming).

12. Alfaro-Velcamp, Theresa, So Far from Allah, So Close to Mexico: Middle Eastern Immigrants in Modern Mexico (Austin, TX: University of Texas Press, 2007).

13. See, for example, Clarence-Smith, W. G., 'Hadhrami Entrepreneurs in the Malay World, c. 1750-c.1940', in Ulrike Freitag and W. Clarence-Smith (eds), Hadhrami Traders, Scholars and Statesmen in the Indian Ocean, 1750s-1960s (Leiden: Brill, 1997), pp. 297-314.

14. Aslanian, Sebouh David, From the Indian Ocean to the Mediterranean: the Global Trade Networks of Armenian Merchants from New Julfa (Berkeley, CA: University of California Press, 2014).

15. See, for example, Marsden, Magnus, 'Actually Existing Silk Roads', Journal of Eurasian Studies 8(1) (2017): 22-30.

16. Markovits, Claude, Merchants, Traders, Entrepreneurs: Indian Business in the Colonial Era (Ranikhet: Permanent Black, 2008).

17. Cohen, Abner, 'Cultural Strategies in the Organisation of Trading Diasporas', in Clause Meillassoux (ed.), The Development of Indigenous Trade and Markets in West Africa (London/Oxford: International African Institute/Oxford University Press, 1971), pp. 266-84.

18. Markovits, Claude, The Global World of Indian Merchants, 1750-1947 (Cambridge: Cambridge University Press, 2000); Falzon, Mark-Anthony, Cosmopolitan Connections: the Sindhi Diaspora, 1860-2000 (Leiden: Brill, 2004).

19. Buggenhagen, Beth, Muslim Families in Senegal: Money takes Care of Shame (Bloomington, IN: Indiana University Press, 2012); Diouf, M., 'The Senegalese Murid Trade Diaspora and the Making of Vernacular Cosmopolitanism', Public Culture 12(3) (2000): 679-702.

20. Belguidoum, S. and Pliez, O., 'Inconspicuous Globalization Yiwu: the Creation of a Global Market Town in China', Articulo: Journal of Urban Research, online, 2016. 
21. Cf. Amrith, Sunil, 'Tamil Diasporas Across the Bay of Bengal', American Historical Review 114(3) (2009): 547-72; Amrith, Sunil, Crossing the Bay of Bengal: the Furies of Nature and the Fortunes of Migrants (Cambridge, MA: Harvard University Press, 2013).

22. Mathews, G., Lins Ribeiro, G. and C. Alba Vega (eds), Globalization from Below: the World's Other Economy (London: Routledge, 2012), pp. 203-20.

23. See, for example, Buggenhagen, Beth, 'Domestic Object(ion)s: the Senegalese Murid Trade Diaspora and the Politics of Marriage Payments, Love, and State privatization', in Brad Weiss (ed.), Producing African Futures: Ritual and Reproduction in a Neoliberal Age (Leiden: Brill, 2005), pp. 21-53; Buggenhagen, Beth, 'Killer Bargains: Global Networks of Senegalese Muslims and the Policing of Unofficial Economies in the War on Terror', in Anne-Maria Makhulu, Beth Buggenhagen and Stephen Jackson (eds), Hard Work, Hard Times: Global Volatility and African Subjectivities (Berkeley, CA: University of California Press, 2010), pp. 131-49; Sahadeo, Jeff, 'The Accidental Traders: Marginalization and Opportunity from the Southern Republics to late Soviet Moscow', Central Asian Survey 30(3/4) (2011): 521-40; Ferguson, James, Global Shadows: Africa in the Neoliberal World Order (Durham, NC: Duke University Press, 2006); Ong, Aihwa, Flexible Citizenship: the Cultural Logics of Transnationality (Durham, NC: Duke University Press, 1999); Piot, Charles, 'Border Practices', in AnneMaria Makhulu, Beth Buggenhagen and Stephen Jackson (eds), Hard Work, Hard Times: Global Volatility and African Subjectivities (Berkeley, CA: University of California Press, 2010), pp. 150-64.

24. Hart, K., 'Informal Economy', in K. Hart, J. Laville and A. D. Cattani (eds), The Human Economy: a Citizen's Guide (Cambridge: Polity, 2010), pp. 142-54.

25. See, for example, McAlly, Christopher, 'Sino-Capitalism: China's Re-emergence and the International Political Economy', World Politics 64(4) (2012): 741-76; Belguidoum and Pliez, 'Inconspicuous Globalization Yiwu'; Polese, A. and Rekhviashvili, 'Introduction: Informality and Power in the South', Caucasus. Caucasus Survey 5(1) (2017): 1-10.

26. For example, Ho, E., The Graves of Tarim (Berkeley, CA: University of California Press, 2006),

27. Freitag, Ulrike and von Oppen, Achim, “Translocality": An Approach to Connection and Transfer in Area Studies', in Ulrike Freitag and Achim von Oppen (eds), Translocality (Leiden: Brill, 2010), pp. 1-24.

28. Gilroy, Paul, After Empire: Melancholia or Convivial Culture? Multiculture or Postcolonial Melancholia? (London: Routledge, 2004). 
29. Nunan, Timothy, Humanitarian Invasion: Global Development in Cold War Afghanistan (Cambridge: Cambridge University Press, 2016).

30. Israel, Jonathan, 'Diasporas Jewish and non-Jewish and the World Maritime Empires', in I. B. McCabe et al. (eds), Diaspora Entrepreneurial Networks: Four Centuries of History (Oxford: Berg, 2005), pp. 3-26.

31. Marsden, Magnus, Ibañez-Tirado, Diana and Henig, David, 'Everyday Diplomacy: Introduction to Special Issue', Cambridge Journal of Anthropology 34(2) (2016): 2-22; Marsden, Magnus, 'We are Both Diplomats and Traders: Afghan Transregional Traders across the Former Soviet Union', Cambridge Journal of Anthropology 34(2) (2016): 59-75.

32. Cf. Alavi, Seema, Muslim Cosmopolitanism in the Age of Empire (Cambridge, MA: Harvard University Press, 2015).

33. Cf. Aydin. Cemil, The Making of the Muslim World: a Global Intellectual History (Cambridge, MA: Harvard University Press, 2017).

34. Cf. Aslanian, From the Indian Ocean to the Mediterranean.

35. Nunan, Humanitarian Invasion.

36. Marsden and Ibañez-Tirado, 'Repertoires of Family Life'.

37. Ho, E., 'Inter-Asia Concepts for Mobile Societies', Journal of Asian Studies 76(4) (2017): 907-28.

38. Marsden, 'Islamic Cosmopolitanism beyond Muslim Asia'.

39. Cf. Cheuk, Ka-Kin, 'Everyday Diplomacy among the Indian Traders in a Chinese Fabric Market', Cambridge Anthropology 35(2) (2016): 42-58.

40. Dale, S. F., The Garden of the Eight Paradises: Bäbur and the Culture of Empire in Central Asia, Afghanistan and India, 1483-1530 (Leiden: Brill, 2004); Levi, S., Caravans: Punjabi Khatri Merchants on the Silk Road (London: Penguin, 2016); Markovits, The Global World of Indian Merchants.

41. Marsden, Magnus, 'Mobile Societies and Partial Neighbourhoods: Afghanistan's Central Asian Emigres between Saudi Arabia and Yiwu', History \& Anthropology (forthcoming).

42. Pliez, 'Following the New Silk Road between Yiwu and Cairo'.

43. Ibañez-Tirado, 'Hierarchies of Trade in Yiwu and Dushanbe'.

44. Ibañez-Tirado, 'Hierarchies of Trade in Yiwu and Dushanbe'.

45. See, for example, Erie, Matthew, China and Islam: the Prophet, the Party, and Law (Cambridge: Cambridge University Press, 2016).

46. Bodomo, A. and Ma, G., 'From Guangzhou to Yiwu: Emerging Facets of the African Diaspora in China', International Journal of African Renaissance Studies: Multi-, Inter- and Transdisciplinarity 5 (2010): 283-9. 
47. Cf. Marsden, 'Mobile Societies and Partial Neighbourhoods'; Green, Nile, 'The Demographics of Dystopia: the Muslim City in Asia's Future', History and Anthropology 27(3) (2016): 273-95.

48. See, for example, Ho, The Graves of Tarim; Osella, F. and Osella, Caroline, "II am Gulf': the Production of Cosmopolitanism in Kozhikode, Kerala, India', in K. Kresse and E. Simpson (eds), Struggling with History: Islam and Cosmopolitanism in the Western Indian Ocean (London: Hurst, 2007), pp. 323-56. 